УДК 351.74

DOI https://doi.org/10.32838/TNU-2663-6468/2020.5/2

\title{
Малишев К.В.
}

кандидат юридичних наук, асистент кафедри права та правоохоронної діяльності

Державного університету «Житомирська політехніка»

\author{
Хробуст O.O. \\ здобувач кафедри економічної безпеки, \\ публічного управління та адміністурвання \\ Державний університет «Житомирська політехніка»
}

\section{ОСОБЛИВОСТІ ПРАВООХОРОННОЇ ДІЯЛЬНОСТІ В ЗАРУБІЖНИХ КРАЇНАХ}

Забезпечення начіональної безпеки кожної держави є однією із основних проблем сучасності. Зарубіжні краӥни на сьогодні мають значні напрацювання як щедо слідчих та прочесуальних дій так $і$ в частині профілактичних заходів, що має стати першочерговим питанням для правоохоронних органів України. Краӥни Європи мають вагомий досвід щодо формування правоохоронної системи. Це обумовлено історичними особливостями та розвитком иивілізаиії в зазначених країнах світу. Варто зазначити, що правоохоронні систем краӥн Свропейського Союзу досить часто піддавали трансформаціям, але в водночас деяким правоохоронним органам в окремих країнах вже понад 100 років.

Сьогодні, в умовах модернізаиії всісї системи державної служби в Україні, реформування правоохоронних органів, їх інтеграмії в правоохоронну систему зарубіжних країн, виникає потреба у вдосконаленні правоохоронних органів України, оптимізації підготовки кадрів, особливо керівних кадрів, здійсненні системних змін в правовому регулюванні професійної діяльності та соиіального забезпечення прачівників. Питання реформування є досить актуальним як з теоретичної, так $i$ практичної точок зору, яке назріло ще з початком отримання незалежності та прийняття Конституції України. Проте, незважаючи на зусилля окремих політиків, обтрунтування та доводи вчених, значних рушійних трансформачій в правоохоронній системі не відбувалися. На сучасному етапі реформування органів внутрішніх справ важливо побудувати модель, щяо найбільше відповідає вимогам міжнародних стандартів та начіональним інтересам.

Основними векторами нашого дослідження стали краӥни Європейського Союзу та високорозвинені країни. Було визначено, ще потреба в налагодженні комунікаиї із правоохоронними органами зарубіжних краӥн набуває важливого значення. Застосування досвіду крайн Європейського Союзу можливе в частинні створення спецііалізованих правоохоронних органів, розширення спектру повноважень представників Бюро економічної безпеки, застосування спільних ресурсів та налагодження співпраці щодо підготовки та перепідготовки кадрів правоохоронних органів.

Ключові слова: правоохоронна діяльність, реформування, правоохоронна система, правоохоронні органи, зарубіжний досвід.

Постановка проблеми. Питання реформування правоохоронної системи України назріло вже досить тривалий час тому, проте відсутність політичної волі, корупція в системі державного управління та сукупність інших факторів, не дозволило сформувати комплекс заходів із реформування. Реформування системи правоохоронних органів України не можливе без врахування сучасних тенденцій розвитку правоохоронних систем зарубіжних країн. Це обумовлено тим, що налагодження взаємодії між правоохоронними органами зарубіжних країн та міжнародними поліцейськими організаціями.
Аналіз останніх досліджень та публікацій. Питання розвитку правоохоронних систем в країнах світу піднімалися в працях вітчизняних вчених, зокрема: В.Б. Авер'янов, О.Ф. Андрійко, М.І. Ануфрієв, Д.М. Бахрах, Ю.П. Битяк, С.В. Бобровник, В.І. Борисов, І.Л. Бородін, С.Д. Гусарєв, І.П. Голосніченко, Є.В. Додін, В.О. Свдокимов, А.П. Заєць, Р.А. Калюжний, В.В. Коваленко, Л.В. Коваль, І.Б. Коліушко, Л.М. Колодкін, М.І. Козюбра, А.М. Колодій, В.В. Копєйчиков, О.Л. Копиленко, В.К. Колпаков, А.Т. Комзюк, М.В. Корнієнко, В.С. Куйбіда, Л.Р. Наливайко, О.В. Негодченко, В.І. Олефір, В.Л. Ортинський, А.Ю. Олійник, 
Н.М. Оніщенко, О.В. Петришин, О.С. Передерій, С.В. Пєтков, В.М. Плішкін, В.Я. Тацій, П.М. Рабінович, Ю.С. Шемшученко, О.Г. Шило, В.К. Шкарупа та інші.

Зважаючи на вагомий внесок вітчизняних та зарубіжних вчених в питання розвитку правоохоронних систем інших країн, сьогодні залишаються невирішеними сукупність проблемних питань.

Постановка завдання. Проаналізувати особливості правоохоронних систем зарубіжних країн.

Виклад основного матеріалу. Важливість зарубіжного для реформування правоохоронної системи України полягає в наступних особливостях:

- по-перше, передові механізми боротьби із злочинністю, мають бути використання при формуванні інституційного, правового, організаційного, інформаційного та інших складових реформування;

- по-друге, для цілей боротьби із транскордонною злочинністю, важливим $є$ механізм взаємодії iз правоохоронними органами зарубіжних країн;

- по-третє, ресурсне забезпечення правоохоронних органів України не в повній мірі відповідає вимогам, які б дозволили ефективно запобігати та протидіяти зло чинам, забезпечувати громадський порядок та безпеку соціальних систем.

Вказані особливості визначають, необхідність вивчення зарубіжного досвіду реформування правоохоронної системи, що дозволить ідентифікувати ключові механізми. Основними векторами дослідження стануть країни Європейського Союзу та високорозвинені країни.

Варто наголосити на спільних рисах правоохоронних систем Європи, які виділяються вченими:

- розгалуженість і різноманітність поліцейських систем, наявність поліцейських органів у різних міністерствах і відомствах, незалежність їх одна від одної. Звідси випливає відповідна побудова системи підготовки фахівців, орієнтованість iii не лише на загальні завдання правоохоронної діяльності, а, передусім, на специфіку конкретної роботи в конкретній поліцейській службі. У результаті максимально скорочується період адаптації до професійної діяльності, набуття необхідної ефективності;

- поділ поліцейських структур за джерелами фінансування на державні, муніципальні (місцевого самоврядування), приватні (фірм, концернів, синдикатів тощо) за умов тісної співпраці між ними;

- соціальна спрямованість роботи поліції, яка орієнтована, насамперед, на захист прав і свобод громадянина;
- високий професіоналізм поліції, який досягається не лише завдяки глибокій професійній підготовці у фахових поліцейських закладах освіти. Поліцейські у США, Великій Британії, Франції та інших країнах змушені навчатись протягом всієї служби, оскільки від цього залежать кар'єра, присвоєння офіційного чину, рівень оплати праці, пільги тощо;

- позапартійність у роботі поліції, що накладає певні обмеження на прояви політичних, партійних переконань, забезпечує неупередженість у службовій діяльності поліцейських, усвідомлення і переконання того, що поліція служить народові, державі, а не окремим партіям, кланам, групам;

- активна діяльність громадських добровільних об'єднань, спрямована на підтримку і допомогу поліції;

- відкритість, гласність, постійна апеляція до громадської думки при розв'язанні складних ситуацій, що виникають у правоохоронній практиці, забезпечують поліції довіру і підтримку населення [7, с. 31].

Розглянемо особливості формування, розвитку та реформування правоохоронних систем наступних європейських країн: Італія, Франція, Іспанія, Великобританія.

\section{Італія.}

Щодо запобігання та протидії економічній злочинності та забезпечення національних інтересів Італії в економічній сфері, функціонує Фінансова гвардія. Даний правоохоронний орган функціонує як спеціалізоване військове формування, основним напрямком якого $є$ протидія економічним злочинам. Основною метою Фінансової гвардії Італії $\epsilon$ захист національний інтересів Італії в фінансово-економічній та військово-політичний сферах суспільних відносин.

Варто зазначити, що Фінансова гвардія Італії $€$ одним із найстаріших правоохоронних органів, адже була створена у 1907 р., а іiі функції перетинаються як 3 цивільними напрямами забезпечення економічної безпеки так і військовими, якщо мова йде про військові дії. «У мирний час Фінансова Гвардія функціонувала під загальним керівництвом Міністерства фінансів, а іiі взаємодія з іншими правоохоронними структурами координувалась Міністерством внутрішніх справ. Королівським декретом для новоствореного поліцейського формування засновувалося прапор та спеціальна уніформа для особового складу, його штатний розклад, дислокація, функціональні обов'язки (для вищих чинів), оклади та пільги [1].

Рєзнік О.М. [8] вказує на наступні завдання Фінансової Гвардії Італії: 
- податковий контроль;

- нагляд за акцизами;

- митний контроль, контроль витрачання державних коштів;

- протидія організованій злочинності;

- фальшивомонетництво;

- запобігання та протидія шахрайству в системі Свросоюзу;

- нагляд за законністю при проведенні державних закупівель, розміщенні замовлень, проведення торгів;

- захист патентів, авторських прав, в т.ч. захист національної продукції та італійських торгових марок;

- захист культурної та археологічної спадщини Італії;

- організація взаємодії з іншими правоохоронними, контролюючими органами країни.

Для забезпечення зазначених завдань дана організація в своїй структурі містить 6-ть міжобласних командувань, інспекторське управління щодо підготовки та перепідготовки кадрів; 20-ть обласних командувань; командування спеціальних відділів; повітряно-морського центрального командування; відділів технічної, адміністративної та тилової підтримки та 102 командувань провінцій. Важливе значенні в забезпеченні національної економічної безпеки займають наступні підрозділи, діяльність яких координується командування спеціальних підрозділів (табл. 1).

Особливою сферою діяльності Фінансової гвардії Італії $є$ можливість здійснення процесуальних дій, зокрема виконує функції кримінальної поліції, що пов’язанні із організацією збору інформації, ведення слідства щодо злочинів, проведення обшуків, затримувати підозрюваних.

Функціональні напрями діяльності Фінансової гвардії Італії є подібними до новоствореного в Україні правоохоронного органу - Бюро економічної безпеки, що перейняв на себе функції податкової поліції та структурних підрозділів національної поліції, які запобіганням та протидією економічним злочинам. Щодо можливості застосування досвіду Італії в даному напрямку є необхідність розширення спектру повноважень представників Бюро економічної безпеки.

\section{Франція.}

Французька правоохоронна система має свої особливості в контексті перетину функціонального спрямування правоохоронних органів, що мають цивільне та військове значення. Вітчизняний дослідник правоохоронних систем зарубіжних країн В.Г. Гриценко вказує на особливості правоохоронної системи Франції:

- по-перше, у Франції правоохоронні органи функціонують у системі органів виконавчої влади, охоплюючи такі сфери суспільних відносин, як внутрішні справи, фінанси, економіка, оборона тощо;

- по-друге, аналізуючи структуру та організацію правоохоронних органів Франції, слід відмітити, що ця держава, на відміну від Великої Британії, має аж два види національних поліцейських сил: 1) Національну поліцію (Police Nationale) та 2) Національну жандармерію (Gendarmarie Nationale);

- по-третє, у Франції функціонує Префектура поліції Парижа (Prefecture de police de Paris), яка

Характеристика діяльності спеціальних підрозділів, що направленні на запобігання та протидію економічній злочинності

\begin{tabular}{|c|c|}
\hline Назва підрозділу & Характеристика діяльності \\
\hline $\begin{array}{l}\text { Командування захисту } \\
\text { державних фінансів }\end{array}$ & $\begin{array}{l}\text { проводить вивчення витрачання державного бюджету та бюджетів } \\
\text { муніципалітетів, а також вивчає факти шахрайства як у країні, так і в рамках } \\
\text { Євросоюзу, на підставі всебічної аналітичної роботи, що проводиться, розробляє } \\
\text { плани (т.зв. проекти) заходів для територіальних підрозділів відомства }\end{array}$ \\
\hline $\begin{array}{l}\text { Командування захисту } \\
\text { економіки }\end{array}$ & $\begin{array}{l}\text { До завдань цього підрозділу належить захист державних заощаджень, руху } \\
\text { внутрішньодержавних грошових потоків, фінансових ринків, зокрема. за } \\
\text { допомогою боротьби з нецільовим використанням державних коштів, протидії } \\
\text { відмиванню незаконно одержаних доходів, а також організованої злочинності } \\
\text { в економічній сфері. Для виконання зазначених завдань призначені підрозділи } \\
\text { з валютних злочинів та Центральної слідчої служби з протидії організованій } \\
\text { злочинності }\end{array}$ \\
\hline $\begin{array}{l}\text { Командування } \\
\text { спеціальних підрозділів }\end{array}$ & $\begin{array}{l}\text { безпосередньо взаємодіє з регіональною владою, парламентськими комісіями } \\
\text { з розслідування, Верховним комісаром із запобігання та протидії корупції та } \\
\text { іншим незаконним явищам, а також іншими органами влади. Повітряно-морське } \\
\text { центральне командування здійснює організацію, координацію та контроль } \\
\text { оперативної, тилової та адміністративної діяльності }\end{array}$ \\
\hline
\end{tabular}

